NBER WORKING PAPER SERIES

\title{
BANKS AS LIQUIDITY PROVIDERS: AN EXPLANATION FOR THE CO-EXISTENCE OF LENDING AND DEPOSIT-TAKING
}

\author{
Anil K Kashyap \\ Raghuram Rajan \\ Jeremy C. Stein \\ Working Paper 6962 \\ http://www.nber.org/papers/w6962
NATIONAL BUREAU OF ECONOMIC RESEARCH
1050 Massachusetts Avenue
Cambridge, MA 02138
February 1999

We thank Eric Bettinger and Qi Chen for valuable research assistance and Melissa Cunniffe for help in preparing the manuscript. Thanks also to George Pennacchi, Gary Gorton, and seminar participants at the Chicago Fed's Bank Structure Conference, the NBER, the University of Chicago, Michigan, UBC, UCSD, UCLA, and Vanderbilt for their comments and suggestions. Research support from the following sources is gratefully acknowledged: the NSF (Kashyap, Rajan, Stein) the University of Chicago GSB Faculty Research Fund (Kashyap) the Federal Reserve Bank of Chicago (Kashyap) CRSP (Rajan), and MIT's Finance Research Center (Stein). The views expressed here are those of the author and do not reflect those of the National Bureau of Economic Research.

(0) 1999 by Anil K Kashyap, Raghuram Rajan, and Jeremy C. Stein. All rights reserved. Short sections of text, not to exceed two paragraphs, may be quoted without explicit permission provided that full credit, including ${ }^{\circledR}$ notice, is given to the source. 
Banks as Liquidity Providers: An Explanation for the Co-Existence of Lending and Deposit-Taking Anil K Kashyap, Raghuram Rajan, and Jeremy C. Stein

NBER Working Paper No. 6962

February 1999

\section{ABSTRACT}

This paper addresses the following question: what ties together the traditional commercial banking activities of deposit-taking and lending? We begin by observing that since banks often lend via commitments, or credit lines, their lending and deposit-taking may be two manifestations of the same primitive function: the provision of liquidity on demand. After all, once the decision to extend a line of credit has been made, it is really nothing more than a checking account with overdraft privileges. This observation leads us to argue that there will naturally be synergies between the two activities, to the extent that both require banks to hold large volumes of liquid assets (cash and securities) on their balance sheets: if deposit withdrawals and commitment takedowns are imperfectly correlated, the two activities can share any deadweight costs of holding the liquid assets. We develop this idea with a simple model, and then use a variety of data to test the model's empirical implications.

Anil K. Kashyap

Graduate School of Business

University of Chicago

1101 East 58th Street

Chicago, IL 60637

and NBER

anil.kashyap@gsb.uchicago.edu
Jeremy C. Stein

Sloan School of Management

MIT

E52-434

50 Memorial Drive

Cambridge, MA 02141-1347

and NBER

jcstein@mit.edu

Raghuram Rajan

Graduate School of Business

University of Chicago

1101 East 58th Street

Chicago, IL 60637

and NBER

raghuram.rajan@gsb.uchicago.edu 


\section{Introduction}

What are the defining characteristics of a bank? The standard answer is that commercial banks are institutions that simultaneously engage in two distinct types of activities, one on each side of the balance sheet: deposit-taking and lending. More precisely, deposit-taking involves issuing claims that are riskless and demandable, that is, claims that can be redeemed for a known value at any time. Lending involves acquiring costly information about opaque borrowers, and offering credit based on this information.

A great deal of theoretical and empirical analysis has been devoted to understanding the circumstances under which each of these two activities might require the services of an intermediary, as opposed to being implemented in arm's-length securities markets. While much has been learned from this work, with relatively few exceptions it has not addressed a fundamental question: why is it important that one institution carry out both functions under the same roof? ${ }^{1}$ For example, Diamond (1984) provides a convincing argument that some types of loans will have to be made by intermediaries, but it is hard to see in his model why the intermediary cannot be a non-bank finance company that is funded with short term debt, rather than a commercial bank that is funded with demand deposits. Similarly, Gorton and Pennacchi (1990) show that intermediation can be valuable in creating adverse-selection-free demand deposits, but it is again not obvious why this service cannot be provided by mutual funds that invest only in liquid securities (e.g., high-grade commercial paper and T-bills) and do not make any loans that involve monitoring.

The question of whether or not there is a real economic synergy between deposit-taking and lending has far-reaching implications. On the one hand, if one takes the view that there is no underlying synergy, the fact that commercial banks engage in both activities might be interpreted as resulting from either past or

\footnotetext{
${ }^{1}$ These exceptions include Calomiris and Kahn (1991), Diamond and Rajan (1998), Flannery (1994), and Qi (1998). We discuss some of these papers in more detail below.
} 
current distortions in the regulatory environment. For example, it might be argued that deposit insurance has encouraged an artificial gluing together of the two activities, as banks attempt to maximize the value of the insurance put option by engaging in risky lending. Under this view, one would naturally tend to be sympathetic to "narrow banking" proposals, which effectively call for the breaking up of banks into separate lending and deposit-taking operations that would resemble finance companies and mutual funds respectively. ${ }^{2}$ On the other hand, if there is a real synergy, a forced switch to narrow banking could lead to large inefficiencies.

In a similar vein, many theories of the monetary transmission mechanism-particularly those that stress the so-called "bank lending channel"-hinge crucially on the assumption that banks engage in both deposit-taking and lending. ${ }^{3}$ To the extent that these theories are true, if the issuing of reservable demand deposits were to be decoupled from the function of extending monitored credit to individuals and businesses, the conduct of monetary policy could be noticeably altered.

In this paper, we argue that there may be significant economic synergies between deposit-taking and lending. We begin by focusing on a product that, in our view, is important in distinguishing banks from other lenders such as insurance companies and finance companies: loan commitments, or credit lines (we use the two terms loosely and interchangeably in what follows). We take the central feature of a commitment to be that a borrower has the option to take the loan down on demand over some specified period of time. ${ }^{4}$ Simply put, once the decision to extend a commitment has been made, it behaves just like a

\footnotetext{
${ }^{2}$ For narrow banking arguments along these lines, see Simons (1948), Bryan (1988), Litan (1988) and Gorton and Pennacchi (1992).

${ }^{3}$ See e.g.: Bernanke and Blinder (1988) and Stein (1998) for the theory behind the lending channel; Bernanke and Blinder (1992), Kashyap, Stein and Wilcox (1993), Ludvigson (1998), Kishan and Opiela (1998), Kashyap and Stein (1998) and Morgan (1998) for supporting evidence; and Kashyap and Stein (1994) for a survey.

${ }^{4}$ Holmstrom and Tirole (1998) also stress that a key function of an intermediary is to provide liquidity in the form of loan commitments. However, they do not link the loan commitment function to the structure of the intermediary's liabilities.
} 
demand deposit: the customer can show up any time and withdraw funds, and these withdrawals will be somewhat random from the bank's perspective. ${ }^{5}$ Or said differently, both demand deposits and loan commitments offer to bank customers a very similar service: the provision of liquidity on demand to accomodate unpredictable needs. ${ }^{6}$

The next step in the argument is the observation that an institution that offers liquidity on demand must invest in certain costly "overhead" in order to carry out its job effectively. In particular, the overhead in our model consists of the large volume of cash and securities that a bank holds as a buffer stock on the asset side of its balance sheet. ${ }^{7}$ Such a buffer stock is required to the extent that capital markets are imperfect, so that a bank cannot accommodate liquidity shocks simply by raising new external finance on a moment's notice. Moreover, this form of overhead is burdensome for a number of reasons. First, on the cash component, there is obviously the foregone interest. Second, even securities that bear a market rate of interest impose a cost on bank shareholders, because of the double taxation of the interest income in the corporate form. Finally, as is frequently argued in the corporate finance literature, a large balance of highly liquid assets gives managers a great deal of discretion, and is likely to increase agency costs (see Myers and Rajan (1998)).

Once it is recognized that both deposits and loan commitments require overhead in the form of cash and securities holdings, and that this overhead is costly, the potential for synergy between the two activities becomes clear. There will be a synergy to the extent that the two activities can "share" some of the costly

\footnotetext{
${ }^{5}$ Anybody who has ever had a home equity line of credit should be able to identify with this point. Once approved by the bank, you may leave the line unused for years, until one day you decide to write a check for $\$ 60,000$ against it to cover an impulse purchase of a new Porsche.

${ }^{6}$ Diamond and Dybvig (1983) point to the intermediary's role in smoothing aggregate liquidity shocks through diversification, but do not emphasize that this can be done across both sides of the bank balance sheet.

${ }^{7}$ Over the period 1992-1996, a typical "small" bank with assets on the order of $\$ 40$ million held roughly $5 \%$ of these assets in cash and another 30\% in securities. For a "large" bank with assets on the order of $\$ 8$ billion, the corresponding figures were $8 \%$ and $20 \%$. See Table 2 below.
} 
overhead, so that a bank that offers both deposits and loan commitments can get by with a smaller total volume of cash and securities on its balance sheet than would two separate institutions that each specializes in only one of the two functions. The synergy exists as long as deposit withdrawals and commitment takedowns are not too highly correlated. Intuitively, a deposit-taking bank holds a buffer stock of cash and securities as a hedge against a state of the world where there are large deposit outflows. But in many other states, there are no deposit outflows, and the buffer stock just sits idle. If the buffer stock can instead be used to accommodate commitment takedowns in these states, efficiency will be enhanced.

A simple example helps to illustrate the logic of our model. Imagine two intermediaries, $F$ (for finance company) and $B$ (for bank) who compete for the same pool of borrowers. The difference is that while $F$ is financed entirely with long-term bonds, $B$ has a "deposit franchise"-i.e., it has a monopoly position that allows it to pay below-market rates on $\$ 100$ of demand deposits. The only hitch with these deposits is that there is some probability that $\$ 20$ of them will be withdrawn unpredictably. Assuming that $B$ cannot raise external finance on short notice, it will have to keep \$20 in cash on hand in order to exploit the rents from its deposit franchise. Now think about $F$ and $B$ competing to attract $\$ 20$ worth of loan commitment business from a firm $X$. If we further assume for simplicity that commitment takedowns are perfectly negatively correlated with deposit withdrawals, it is clear that $B$ will be a lower-cost producer of commitments, because it does not have to add to its cash balance to offer this service. ${ }^{8}$

Thus in this example, the bank $B$ wins firm $X$ 's commitment business. Moreover, once it has sunk the cost of investigating $X$ to ensure that it is a good credit for the commitment, $B$ will also have an advantage in competing with $F$ for other business from $X$ where liquidity provision plays no role-e.g., it might be in a better position to offer $X$ a term loan in addition to the commitment.

\footnotetext{
${ }^{8}$ In our formal model, we relax these assumptions, so that: i) external finance is costly but not impossible to raise; and ii) deposit withdrawals and commitment takedowns need not be negatively correlated, only less than perfectly positively correlated.
} 
The example suggests two broad classes of empirical implications of our theory. First, across types of financial institutions, we should observe commercial banks doing: i) more short-term commitmentbased lending than other intermediaries such as finance companies or insurance companies; as well as ii) more long-term lending to those particular borrowers who are also relatively heavy users of commitments. Second, within the commercial banking sector, those banks that have the most pronounced advantage in offering demandable deposits (as measured, for example, by the ratio of transactions deposits to total deposits) should be expected to: i) hold more in cash and securities; and ii) do a greater fraction of their lending on a commitment basis.

In the remainder of the paper, we develop this theory more fully, and also test some of its principal implications. We start in Section 2 with a brief history of the commercial banking industry which suggests that our basic story is well-motivated. In Section 3 we sketch a simple model that formalizes the intuition from the example above. In Sections 4 and 5, we conduct our empirical tests. To preview, we find strong evidence for two basic propositions. First, banks do more short-term commitment-based lending-especially via unsecured lines of credit-than any other type of lending intermediary. Second, within the banking sector, those banks with high ratios of transactions deposits to total deposits also have high ratios of loan commitments to loans-i.e., banks specializing in demandable deposits also seem to specialize in commitment-based lending, consistent with our theory. Conclusions follow in Section 6.

\section{Historical Overview}

The following sketch is somewhat selectively culled from existing histories and is intended to provide broad motivation for our theory, not systematic evidence.

\subsection{Deposits}

The consensus among historians (see De Roover (1948), Lane and Mueller (1985), and Usher 
(1943) for example) is that deposit banking in Continental Europe evolved from the activity of money changing. The early Middle Ages saw an increasing use of coins rather than barter in trade. There was, however, a problem with the available coins. Coinage was imperfect, so coins could contain very different quantities of metal even when newly produced by the same mint. There were many mints in even a small area, each of which had its own method of production and standard of honesty. Moreover, even after production, the coins could be deliberately clipped or sweated (by shaking them in a bag with other coins so as to remove metal), or the edges could be filed (milling of the edges was introduced only in the sixteenth century). Further, the coins were subject to normal wear and tear. Sometimes, the mint systematically reduced the precious metal content in coins, bringing its prior coinage into disrepute. Given that coins were of differing quality, traders offered the worst acceptable coins in their possession for trade, further reducing the quality of coins in circulation. So while money eliminated the problem of double coincidence of wants inherent in barter, a new impediment to trade arose-uncertainty about the value of the money.

The money changers helped mitigate this uncertainty. The money changer specialized in coins, so he knew both foreign and local coins, could distinguish the counterfeit from the genuine, knew bullion and exchange rates, as well as the extent to which different coins were depreciating. So he could make an assessment as to whether a debased coin would be acceptable at face value or be valued only for its metal content. He used this knowledge to perform two functions.

First, he valued the foreign or debased coins that a customer brought in and exchanged them for local coins that could circulate easily. Of course, for the money changer to play a useful role, not only did he have to have expertise in coins, but he also had to have a reputation for honesty in his dealings-or else the public would fear rather than welcome his expertise.

Second, the money changer separated the coins into those he would send back to the mint for recoinage, and those he could reintroduce into circulation. He chose who to give which coins to. For instance, debased coins were less valuable in large payments where coins were weighed but they could still fetch 
their face value in small payments. Thus the money changer also served what might be termed a placement function today.

It was a small step from changing money to opening deposit accounts. When a trader brought in coins, the money changer could open an account for the trader rather than giving him new coins. If the trader wanted to pay a supplier money, the money changer would simply make an accounting entry, debiting the trader's account. If the supplier had an account with the money changer, the money changer would credit the account, thus reducing the entire payment transaction to pen strokes. It was not much harder to make the payment if the supplier had an account with another money changer. Over a period-say a day-the money changers would cumulate all the payments and receipts for their respective clients and make only the net payment to each other in cash after which the necessary accounting entries would be made. Because payments were pooled then netted, deposit banking reduced the overall volume of payments made in coins. Furthermore, it allowed merchants to leave the business of dealing in uncertain coinage entirely to the network of money changers, letting merchants focus on what they knew best; production and trade. Thus deposit banking and banking networks were born to facilitate payments.

\subsection{Overdrafts}

The money changer had to maintain a reserve of coins so as to make net payments to other bankers and to meet withdrawals by depositors. But not all the cash that was initially deposited had to be maintained as reserve since only a fraction of depositors would need their money at any time. Fractional reserve theories of banking suggest that banks channeled idle cash into loans to entrepreneurs.

However, the nature of the loans made, as well as the identity of the recipients, was determined by the deposit business. Banks typically did not make long term loans (though these were no more illiquid than the unsecured loans they did make). Instead, the early private banks allowed depositors to borrow by overdrawing their account (e.g., Usher (1943), p 18). These overdrafts were thus loans obtained virtually 
on demand by depositors. From the perspective of the money changer, the overdraft facility (or its modern equivalent, the line of credit) was essentially the same as a deposit. Both products required the money changer to come up with cash on demand, i.e., they were products through which the money changer provided liquidity. While with the overdraft facility, the money changer was not legally required to make the loan (he could refuse to allow the overdraft), in practice the difference was probably moot; once customers came to rely on the money changer's overdraft facility, it would hurt his reputation almost as much if he refused to allow it without good reason, as it would if he refused to pay out on deposits.

Given that deposits and overdrafts were essentially the same product, the money changer could spread his fixed costs over a larger volume of business if he offered both. Once the money changer had invested in the physical infrastructure-building, strong box, guards-to keep the cash reserves he needed to meet unexpected deposit withdrawals, and once he had established a network with other money changers (so that he could call on their liquidity if his own reserves proved inadequate), he could use the same security arrangements and relationships to meet unexpected overdrafts.

Moreover, in the small trading economies of that period, he probably did not have to keep much more additional cash as reserve to service the overdrafts, and any reserve could be worked much harder. There typically must have been a balance between deposit inflows and overdraft outflows in a closed trading economy. As a somewhat simplistic example, at harvest time, the farmer would sell grain and be flush with cash so he would be a net depositor while the grain merchant would carry an overdraft. During the rest of the year, the grain merchant would pay down the overdraft as he sold the grain while the farmer's deposit balances would lapse into overdraft before the next harvest. The lending and borrowing by the farmer and the grain merchant would covary naturally in such a way as minimize the demands on the bank's reserve. Only a dramatic failure of the harvest, or disproportionate growth of a particular sector, would upset the natural harmony and destabilize the bank. Thus, the liquidity demands of customers could be diversified and smoothed in natural ways if the money changer offered both deposits and overdrafts. 
Early bankers thought this natural diversification of liquid reserves across demands to be the

primary advantage of banks. Hammond (1957, p55-58) cites Senator Robert Morris of Pennsylvania, who

made the following statement to the Philadelphia Assembly in 1785.

By becoming stockholders in a bank, the merchants had pooled their cash to make it go further. But there were very few of them, Mr Morris said "who do not stand in need of the whole of their money in the course of business, and when in need they borrow occasionally perhaps the whole amount or more". Further, "it is upon these principles the merchants generally remain stockholders - when one does not want his money, it is earning his share of the dividend from another; and by thus clubbing a capital together, as it were, the occasional wants of all are supplied." Why, he asked in substance, should not the merchants do collectively and conveniently what they had used to severally and inconveniently?

It is clear that the term 'stockholder' is used in the same sense as we have used 'depositor' above. What is interesting is that Morris makes little attempt to distinguish between merchants withdrawing the money they deposited and their borrowing anew. Thus deposits and lines of credit were thought of then, much as we advocate in this paper, as similar products drawing on common resources. As another senator, Thomas Fitzimons remarked during the debate, in the absence of a bank, "every merchant or trader must at all times have money in his chest or in his drawer unemployed". The bank made these several hoards unnecessary (Hammond (1957, p 57)). In what follows, we formalize this historical rationale for a bank.

\section{The Model}

\subsection{Framework}

The model is designed to capture in a minimalist fashion the following characteristics of a bank:

(i) the bank's role is to provide funds to its customers on demand; but (ii) it finds it costly to raise external finance unexpectedly; so (iii) it maintains a buffer stock of liquid assets; and (iv) holding the buffer stock is also costly. Note that (ii) and (iv) imply that the model will have to incorporate two distinct capital market frictions: there needs to be an ex post flow cost of raising new external finance, as well as an ex ante stock 
cost of holding liquid assets. ${ }^{9}$ As we discuss further below, the former can be motivated based on an adverse-selection argument in the spirit of Myers (1984) and Myers and Majluf (1984), while the latter can be motivated based on a variety of factors, including taxes and agency costs.

There are three dates: 0,1 , and 2 . The short-term interest rate on securities is exogenously fixed in this partial-equilibrium framework, and is $i$, both between date 0 and date 1 , as well as between date 1 and date 2. For notational simplicity, we assume that all interest-as well as all other fees and charges-is paid out at date 2. This avoids compounding, and means that someone investing a dollar in securities at date 0 will accumulate total interest of $2 i$ at date 2 .

\section{Assets}

The bank makes term loans $L$ at date 0 which mature and are paid off at date 2 . The two-period rate on these loans is $r(L)$. We assume that the bank has some market power in lending (see Hannan (1991) and Cosimano and McDonald (1998)) which implies that $r_{L}<0$. The assumption of market power is only to limit the scale of lending activities, and an assumption about increasing costs of making loans would achieve the same end. The details of what drive loan demand are unimportant for our purposes, so this simple reduced-form approach is sufficient.

In addition to the term loans, the bank can also hold an amount $S_{0}$ of liquid assets-e.g., cash, central bank reserves or treasury bills-on its balance sheet between date 0 and date 1 . These assets earn the security-market interest rate of $i$, but we assume that this is at least in part offset by a proportional deadweight cost of $\tau$ per dollar held. Thus the net return on the liquid assets from date 0 to date 1 is $(i-\tau) S_{0 .}$ As suggested above, one can attach a number of interpretations to the parameter $\tau$. Perhaps the simplest case is to think of $S_{0}$ as literally invested in cash or non-interest-bearing reserves, so that $\tau=i .^{10}$

\footnotetext{
${ }^{9}$ Froot and Stein (1998) develop a model of a bank with exactly this structure.

${ }^{10}$ Somewhat more subtly, one might make a similar argument for banks' holdings of short-term T-bills, to the extent that the prices of these T-bills reflect a general equilibrium liquidity premium above and beyond what would
} 
Alternatively, $\tau$ might be taken to reflect the (unmodelled) tax or agency costs associated with holding financial slack. Myers and Rajan (1998) argue that for financial institutions, the agency problems associated with holding liquid assets may be particularly severe, as there is much scope for risk-shifting or asset substitution. Thus the ex ante expected return on liquid assets, net of financing costs, may be negative.

At date 1, some of the liquid assets may be drawn down, leaving a remaining balance of $S_{1}$ to be held until date 2. This remaining balance continues to earn the rate $i$ between date 1 and date 2 , but for simplicity we assume that there is no longer any deadweight $\operatorname{cost} \tau$. Under the interpretation where the liquid assets had to be held in cash between date 0 and date 1 to meet unexpected liquidity demands, this would correspond to assuming that the cash can now be rolled over into interest-bearing securities, thereby eliminating the opportunity cost. Alternatively, under the interpretation where there are tax or agency costs of holding securities, one can imagine that the quantity $S_{1}$ is actually deployed more efficiently by paying down some of the bank's existing market-rate debt (see below). In this case, $S_{l}$ is not literally held on the asset side of the balance sheet, but rather represents a "contra" account against the liability side, an account which is implicitly earning an economic return of $i$.

\section{$\underline{\text { Liabilities }}$}

The total assets to be financed at date 0 are $L+S_{0}$. They are financed partly by demandable deposits. Demand deposits pay no interest at any time, so the bank will take all it can get at date 0 . We assume that the amount, $D_{0}$, is exogenously determined, for example, by the kind of customers living in the

obtain in a standard perfect-markets model. In other words, because they can be used in an almost money-like fashion in a variety of transactions (repurchase agreements, etc.) short-term T-bills may, like money, have an implicit "convenience yield" and thus offer a lower rate of return relative to other assets than can be explained solely by differences in risk. For a related discussion of the equilibrium premium for asset liquidity, see Holmstrom and Tirole (1997). 
immediate neighborhood of the bank. ${ }^{11}$ Thus $D_{0}$ can be thought of as a measure of the value of the bank's deposit-taking franchise. The disadvantage of deposits is that a random fraction $\omega$ of those who deposit at date 0 may withdraw to meet their liquidity needs at date 1 , where $\omega$ is 0 or 1 with equal probability. ${ }^{12}$

In addition to deposits, the bank can also issue claims in the public market at either date 0 or date 1 , denoted by $e_{0}$ and $e_{1}$ respectively. These claims mature at date 2 , and can be thought of as either bonds or equity. We assume that there are no information asymmetries between the bank and investors at date 0 , so that the cumulative rate paid on any (two-period) claims issued at this time is $2 i$.

However, at date 1 , there is the potential for adverse selection in the capital market, perhaps because the bank has gained some inside information as to the quality of its loan portfolio. We could in principle model this adverse-selection problem explicitly; however for the sake of transparency we adopt a very simple quadratic formulation where the total cost of incremental funds $e_{1}$ raised at date 1 is given by $i e_{1}+\alpha e_{1}^{2} / 2$. Here $\alpha$ measures the degree of capital market imperfection-the larger it is, the more costly is external financing relative to the frictionless case. ${ }^{13}$

\section{$\underline{\text { Commitments }}$}

Finally, the bank may issue loan commitments at date 0 , which obligate it to provide funds to borrowers on demand at date 1 . We skirt the interesting and important question of why firms or consumers

\footnotetext{
${ }^{11}$ All that really is needed is that the deposit rate be less than $i$, so the bank earns rents on its deposit franchise and will be willing to invest in securities to support it.

${ }^{12}$ It is not important for our results that all the deposits be at risk for withdrawal-all that we require is that some non-zero fraction be at risk. Even with a very large number of depositors, this is likely to be the case as long as there is some systematic component to liquidity demand. One can imagine many factors that might give rise to such a systematic component. (A bank run is an extreme example.)

${ }^{13}$ Although this quadratic formulation may appear ad hoc, Stein (1998) derives almost exactly the same reduced form in a more formal model where there is adverse selection with respect to a bank's uninsured nondeposit liabilities. Our $\alpha$ parameter can be mapped directly into the parameter $A$ in that paper, which is a measure of the information asymmetry between bank managers and investors.
} 
might wish to enter into commitment arrangements. ${ }^{14}$ Instead, we just assume an exogenous demand for commitments, and again endow the bank with some market power. Specifically, if the bank sells $C$ dollars worth of commitments at date 0 , it receives a total fee at date 2 of $f C$ where $d(f C) / d C>0, d^{2}(f C) / d C^{2} \leq 0$. At date 1 , a random fraction $z$ of the commitments are taken down, where $z$ is 0 or 1 with equal probability. Those borrowers who do take down the commitments pay an interest rate of $i$ on the balance outstanding between date 1 and date $2 .{ }^{15} \quad$ We assume that the probability deposits are withdrawn $(\omega=1)$ conditional on commitments being drawn down $(z=1)$ is $\rho$. So if $\rho=1 / 2$, the withdrawal of demand deposits and the takedown of loan commitments are independent events; if $\rho=1$, they are perfectly positively correlated; and if $\rho=0$, they are perfectly negatively correlated. ${ }^{16}$

\subsection{Solving the Model}

With all the assumptions in place, we are now ready to solve for the bank's optimal choice of $L$ (term loans), $C$ (commitments), and $S_{0}$ (liquid assets). The bank seeks to maximize its expected net income, denominated in date-2 dollars:

$$
\operatorname{Max} E\left\{r L+f C+i z C+(i-\tau) S_{0}+i S_{1}-2 i e_{0}-i e_{1}-\alpha e_{1}^{2} / 2\right\}
$$

In so doing, it faces the following constraints:

\footnotetext{
${ }^{14}$ Holmstrom and Tirole (1998) address this question directly, and their paper can be thought of as providing the micro-foundations for the commitment demand that we simply take as exogenous.

${ }^{15}$ Setting the interest rate on the outstanding balance to $i$ in this way is an innocent normalization.

${ }^{16}$ The withdrawal of demand deposits and the takedown of loan commitments can be less than perfectly correlated even if there are large numbers of depositors and borrowers. Depositors and borrowers may come from different segments of the population and so may have different liquidity demands. Alternatively, the two groups may have different incentives. For instance, in a bank run, depositors have an incentive to withdraw their money, while borrowers have little incentive to take down commitments.
} 


$$
\begin{aligned}
& L+S_{o}=D_{0}+e_{0} \\
& L+S_{1}+z C=D_{0}(1-\omega)+e_{0}+e_{1} \\
& S_{1} \geq 0
\end{aligned}
$$

Constraints (2) and (3) are simply balance sheet identities for date 0 and date 1 respectively. Since it is costly to raise money from the public at date 1 , the bank will, if need be, liquidate its entire portfolio of liquid assets at date 1 to meet the demands of depositors or borrowers. However, if this is not sufficient, any new funds will have to be obtained through a costly public issue and not through short sales. This is reflected in (4), which indicates that date-1 liquid-asset holdings cannot become negative.

The first order conditions are given by:

$$
\begin{aligned}
& L: \quad r+L r_{L}=2 i \\
& C: \quad f+C f_{C}=\alpha / 2 d E\left(e_{1}^{2}\right) / d C \\
& S_{0}: \quad \tau=-\alpha / 2 d E\left(e_{1}^{2}\right) / d S_{0}
\end{aligned}
$$

The intuition is straightforward. At the margin, loans are financed by issuing two-period claims at date 0 , hence (5). An additional dollar in commitments sold will increase the bank's fee income but will also increase the expected costs of external finance at date 1, hence (6). In contrast, the bank will incur the cost $\tau$ by holding more liquid assets at date 0 , but will save on expected issue costs at date 1 , hence (7). 
Substituting (2) into (3) and applying (4), we have the following expression for the date-1 external financing need:

$$
e_{1}=\operatorname{Max}\left[z C+\omega D_{0}-S_{0}, 0\right]
$$

As can be seen from (8), the value of $e_{1}$ - and hence the nature of the solution to the model-depends on the magnitude of the optimal value of liquid assets, $S_{0}{ }^{*}$, relative to the the initial deposits, $D_{0}$, and the optimal level of commitments, $C^{*}$. In particular, we can identify four different regions:

Region 1: $S_{0}{ }^{*} \leq \min \left(C^{*}, D_{0}\right)$.

Region 2: $C^{*} \leq S_{0}{ }^{*} \leq D_{0}$.

Region 3: $D_{0} \leq S_{0}^{*} \leq C^{*}$.

Region 4: $S_{0}{ }^{*} \geq \max \left(C^{*}, D_{0}\right)$.

It turns out that our key results are driven by what happens in Region 1. So for the purposes of exposition, our focus in the text is primarily on understanding the comparative statics properties of an equilibrium that lies in this region. (In the appendix, we provide a fuller analysis of the other regions.) In Region 1, the bank is forced to raise external finance in three out of the four possible states of the world-if outflows take place on either commitments or deposits, or on both. Using (8), this implies that:

$$
E\left(e_{1}^{2}\right)=\rho / 2\left[\left(C+D_{0}-S_{0}\right)^{2}\right]+(1-\rho) / 2\left[\left(D_{0}-S_{0}\right)^{2}+\left(C-S_{0}\right)^{2}\right]
$$

Substituting (9) into (7), and differentiating, we obtain:

$$
\tau=\alpha / 2\left[C^{*}+D_{0}-S_{0}^{*}(2-\rho)\right]
$$


Therefore:

$$
S_{0}^{*}=\left[C^{*}+D_{0}-2(\tau / \alpha)\right] /[2-\rho]
$$

Similarly, substituting (9) into (6) and differentiating, we have:

$$
f+C^{*} f_{C}=(\alpha / 2) \quad\left[\rho D_{0}+C^{*}-S_{0}{ }^{*}\right]
$$

Substituting $S_{0}{ }^{*}$ from (11) in the right hand side of (12) and simplifying, we get:

$$
f+C^{*} f_{C}=\frac{\alpha\left[\left(2 \rho-\rho^{2}-1\right) D_{0}+(1-\rho) C^{*}+2(\tau / \alpha)\right]}{(4-2 \rho)}
$$

Implicitly differentiating leads to the following comparative statics result:

$$
\frac{d C^{*}}{d D_{0}}=\frac{-\frac{\alpha(1-\rho)^{2}}{(4-2 \rho)}}{\frac{d^{2}(f C)}{d C^{2}}-\frac{\alpha(1-\rho)}{(4-2 \rho)}}
$$

The denominator on the right hand side is negative, and the numerator is negative so long as borrowing on commitments and deposit withdrawals are not perfectly positively correlated $(\rho<1)$. So $C^{*}$ increases with an increase in $D_{0}$. Thus we have established: 
Proposition 1: For parameters such that the equilibrium is in Region 1 where $S_{0}{ }^{*} \leq \min \left(C^{*}, D_{0}\right)$, both the holdings of liquid assets $S_{0}{ }^{*}$ and the quantity $C^{*}$ of commitments that the bank issues at date 0 are increasing in the amount of demand deposits $D_{0}$.

Why is there a synergy between demand deposits and commitments in Region 1? Given that they compete for the same scarce resource at date 1-the store of liquid assets-why don't they tend to crowd each other out? The answer lies in recognizing that the stock of liquid assets is not fixed, but rather is optimally adjusted with changes in deposits. In this region, an increase in deposits leads the bank to bump up liquidasset holdings to cover the increased withdrawal risk. These extra liquid assets are also available to help if a commitment takedown occurs instead. As long as the commitment and deposit outflows are not perfectly correlated, this explains our synergy.

Another way to understand the source of the synergy is to see when it breaks down. If liquid-asset holdings exceed either the maximum possible deposit withdrawal or the maximum commitment drawdown, so that we are no longer in Region 1, commitments are locally independent of deposits. In particular, we show in the appendix that the analogs to equation (13) for these other regions are given by:

In Region 2: $\quad f+C^{*} f_{C}=\alpha \rho(1-\rho) C^{*} / 2+\rho \tau$

In Regions 3 and 4: $\quad f+C^{*} f_{C}=\tau$

Consider as a specific example Region 3, where liquid assets exceed the maximum possible deposit outflow. In this case, a deposit withdrawal that occurs by itself does not stress the bank's liquidity position. There is only a problem (and hence a need for external finance) when both deposit and commitment outflows occur simultaneously. Thus if there is an increase in deposits in this region, the bank 
will raise its holdings of liquid assets, but just enough to cover the extra risk that both outflows happen at the same time. Consequently, the extra liquid assets which are added provide no scope for the bank to increase its commitments. Indeed, this can be seen from (16), which tells us that the optimal level of commitments in this region is already pinned down, by balancing the (constant) marginal cost of holding liquidity with the marginal revenue from offering the commitments.

Having said something about the local nature of equilibrium within each of the four regions, the next step is to pose the global question: as the level of deposits $D_{0}$ increases from zero to infinity, what happens to liquid-asset holdings and commitments? In the appendix, we prove the following:

Proposition 2: i) As $D_{o}$ moves from zero to infinity, both $S_{0}{ }^{*}$ and $C^{*}$ are weakly increasing, continuous functions. ii) Define $C^{\tau}$ as that value of $C$ such that: $f+C f_{C}=\tau$. If $\tau$ is sufficiently large, such that $C^{\tau}<2 \tau / \alpha \rho$, then Region 4 does not exist. Rather, as $D_{o}$ increases, the equilibrium moves from Region 3 (where $S_{0}{ }^{*}$ is rising and $C^{*}$ is flat), to Region 1 (where both $S_{0}{ }^{*}$ and $C^{*}$ are rising), and then to Region 2 (where $S_{0}{ }^{*}$ is rising and $C^{*}$ is flat).

Figure 1 provides a concrete illustration of the proposition, for a case where: $f(C)=1-.025 C$; $\rho=.5 ; \alpha=.1 ;$ and $\tau=.45$. The proposition and the figure suggest a variety of related empirical implications of our theory. First, comparing across types of financial institutions, non-bank lenders (e.g. finance companies) who are presumably in Region 3 with no demand deposits, should on average hold fewer liquid assets and do less in the way of commitment-based lending than deposit-taking banks, to the extent that at least some banks have sufficient deposits to wind up in Regions 1 or 2. Similarly, within the banking sector, those banks that have more in the way of demandable deposits should hold more liquid assets and do more commitment-based lending.

More specifically, in our empirical work below, we test the following three predictions of the 
model. The first has to do with comparing banks to non-bank lenders, while the latter two involve withinbanking-sector comparisons.

Prediction 1: Deposit-taking banks will offer relatively more commitments than other lending intermediaries. Alternatively, firms will obtain more of their commitments from banks than from other intermediaries.

Prediction 2: Across a sample of banks, an increase in demand deposits should lead to an increase in loan commitments. This prediction is conceptually straightforward, and we test it with a cross-sectional OLS regression of commitments on demand deposits. The most important issues revolve around how we scale these two variables, a subject we discuss in detail in Section 5 below.

Prediction 3: Across a sample of banks, an increase in demand deposits should lead to an increase in liquid-asset holdings, and it is this increase in liquid assets which should cause loan commitments to go up. This prediction is somewhat sharper, and testing it involves two steps. First, we use an OLS regression to check that liquid assets are indeed positively correlated with demand deposits. Then, we run an instrumental variables (IV) regression, where commitments are regressed against liquid assets, with demand deposits serving as an instrument for liquid assets. The IV approach is crucial here. Our model does not necessarily predict that commitments and liquid assets will be unconditionally positively correlated. For example, suppose there is heterogeneity across banks in terms of the parameter $\alpha$, which measures costs of external finance. According to equations (11) and (13), banks with high values of $\alpha$ will hold more liquid assets but may make fewer commitments, thereby potentially inducing a negative correlation in an OLS regression. Our theory only predicts that commitments will be positively correlated with that component of liquid-asset holdings which is driven by demand deposits, hence the IV approach. 


\subsection{An Extension: Implications for Term Lending}

As the model is currently set up, there is no synergy between a bank's deposit-taking activities and its term lending. The amount of term lending is given by (5), and is a function solely of loan demand and the security-market interest rate $i$. However, it is easy to extend the model so as to generate an additional synergy that links the term lending in with commitments, and thus by extension with deposits. Suppose that when a bank offers a line of credit, it must spend some resources to investigate the potential borrower, so as to ensure that he is creditworthy. Once this cost is sunk, the bank will clearly be at an advantage in making a term loan to the same borrower.

Thus it would be inappropriate to interpret our model as saying that banks should be expected to do only commitment-based lending. Quite to the contrary: to the extent that having a deposit franchise encourages a bank to get into the commitment business, being in the commitment business in turn might naturally spill over into doing some non-commitment-based term lending. A potentially more precise implication of this line of reasoning is that one might predict that banks' term lending would be disproportionately tilted towards those types of customers that make relatively heavy use of commitments. For example, if a particular small firm has very volatile working capital needs and is hence a heavy user of bank credit lines, it might be more likely than the average firm to be raising its longer-term funding for plant and equipment from banks too, as opposed to from finance companies.

\subsection{Other Institutions: Money Market Mutual Funds}

Our analysis has implicitly compared banks to finance companies, since a finance company can be thought of as a lender in our model who happens to have a value of $D_{0}$ that is zero. We have thus far had less to say about banks' principal competitors on the liability side of the balance sheet, money market mutual funds. Conceptually, a money market mutal fund can be thought of as having a deposit franchise, much like the banks in our model. However, one can argue that money market funds have a key advantage 
relative to banks-their deadweight cost of holding securities, as given by $\tau$, is much smaller, and may in fact be close to zero.

There are at least two reasons why this is so. First, to the extent that $\tau$ reflects tax factors, the mutual fund form of organization does not suffer from the same double taxation as a banking corporation. Second, to the extent that $\tau$ reflects agency problems, these too are likely to be greatly mitigated in a money market mutual fund. After all, such a fund is typically legally restricted to holding highly liquid, investment grade securities, and it is virtually transparent, with the assets being marked to market on a daily basis. Thus its charter gives its managers much less discretion to engage in the sort of assetsubstitution or risk-shifting activities that drive bank agency problems.

Of course, the flip side of this sort of narrowly-defined charter is that a money market mutual fund simply cannot be in the business of making illiquid loan commitments and term loans. In other words, it can't both have its cake (a deposit franchise without any tax or agency costs) and eat it too (the discretion to engage in traditional, opaque lending-type activities). Thus while one might argue that a non-zero value of $\tau$ is not necessarily an unavoidable consequence of simply taking deposits, we are probably on safe ground in assuming that it is unavoidable if, as in a bank, the asset side of the balance sheet is to consist of something in addition to highly liquid assets.

This line of reasoning makes it clear why it may be hard to design a narrow banking structure that delivers the same economic performance as a bank. Consider a situation where a traditional commercial bank converts itself into a holding company with two legally distinct subsidiaries: a finance company and a money market mutual fund. ${ }^{17}$ At first blush, one might argue that this is an attractive organizational form: having the mutual fund structure allows the deposit franchise to be exploited, while getting rid of the deadweight costs of holding liquid assets. And at the same time, there may still be room to realize some

\footnotetext{
${ }^{17}$ We are grateful to George Pennacchi for suggesting that we think about this example.
} 
economies of scope across lending and deposit-taking under the umbrella of the holding company.

However, one important synergy is lost with this holding company structure. The finance company sub can no longer "raise funds internally" by tapping the liquid assets of the money market mutual fund sub. In other words, if the finance company sub decides to get into the commitment business and it experiences a liquidity shock, it will now have to resort to a costly new issue in the external capital market, since the mutal fund sub is not allowed to invest in loan commitments. By contrast, in an integrated bank, managers have the discretion to sell off liquid assets and rebalance the overall asset portfolio towards illiquid loans if they so choose. This discretion may give rise to agency costs, but, as our model illustrates, it also can have important benefits.

\subsection{Relationship to the Literature}

There are a few other papers that attempt to draw a link between banks' lending and deposit-taking activities. One theme is that bank liabilities may be short term so as to minimize agency costs on the asset side. Calomiris and Kahn (1991) describe demand deposits with sequential service as a way to provide incentives for outside investors to monitor a borrower. Depositors who are the first to withdraw their capital get paid in full, and will have an incentive to anticipate those actions that could reduce the value of

the borrower's assets. Their rush to withdraw in turn alerts passive outside investors that the borrower may be acting against their interest.

The point Calomiris and Kahn make is important, but, as argued by Diamond and Rajan (1998), partly reflects the more general control property of short-term debt, and thus in principle could apply at least as well to an industrial firm as to a bank. So the distinguishing feature of a bank in their model has to be that it suffers from more severe agency problems than an industrial firm. Flannery (1994) suggests that this is indeed the case because bank loans are more opaque, and hence more liable to transformation, than 
industrial-firm assets. ${ }^{18}$

Diamond and Rajan (1998) also take up the question of why demand deposits might impose more discipline on banks than on industrial firms. Their argument is that the threat of runs limits the rents that a bank's management can absorb, while it cannot limit the rents taken by management in an industrial firm. The reason is that in their model, bank managers do not create value, but merely redistribute cash flows once a loan is made. As a result, a change in the pattern of negotiation caused by a run can affect management's share of the rents. In an industrial firm, on the other hand, management directly adds value, and so long as human capital is inalienable, cannot be preventing from obtaining some rents.

What all these models have in common with one another, and what distinguishes them from ours, is that they attempt to explain why illiquid term loans might go together with demandable deposits. Our whole focus has instead been on trying to explain why demandable loan commitments might go together with demandable deposits. Our model does have subsidiary implications for term loans, as discussed above, but they are strictly a byproduct of the synergy between deposits and commitments that we identify.

\section{Evidence on Banks vs. Other Lending Institutions}

\subsection{Data Description}

To investigate Prediction 1, we use the 1993 National Survey of Small Business Finances (NSSBF). This survey, conducted in 1994-95 for the Board of Governors of the Federal Reserve System and the U.S. Small Business Administration, covers a nationally representative sample of small businesses. The target population is all for-profit, non-financial, non-farm business enterprises that had fewer than 500 employees and were in operation as of year-end 1992. The public data set contains 4637 firms, and

\footnotetext{
${ }^{18}$ Myers and Rajan (1998) argue that, to the contrary, bank loans are not subject to transformation risk because they are illiquid. Rather, the agency problem arises withh respect to the liquid assets that a bank must hold.
} 
describes all the loans each firm has as of year-end 1992, as well as the institutions these loans came from.

We want to obtain a picture both of the kinds of loans each institution makes, and conversely, of where a firm typically sources a certain type of loan from. For each firm, we classify each loan based on its type (e.g., line of credit, mortgage, etc.) and the type of financial institution it comes from (e.g., bank, finance company, etc.). We then add up the loans in each loan-type/institution-type bin across all firms. If we divide the total loans in a loan-type/institution-type bin by the total loans made by that type of institution in the sample, we obtain the fraction of the particular loan type in the institution's portfolio. Similarly, if we divide the total loans in a loan-type/institution-type bin by the total loans of the loan-type, we obtain the fraction of all loans of this type made by the particular type of institution.

Note that while this method allows us to obtain a complete picture of where small firms get their loans from, for financial institutions we only obtain the composition of their lending to small firms. The obvious drawback is that institutional lending to other segments of the borrowing population (e.g. large firms) may change the picture considerably, and we have no way to tell by how much. The benefit is that by focusing on a narrow segment of the borrowing population (i.e., small firms) we correct, in a sense, for variations in the nature of service provided through loans, and thus obtain a better measure of the comparative advantage of institutions in making different kinds of loans.

We have one last issue in classifying loans. Our theory suggests that an overdraft (a negative balance) on a demand deposit is identical to a takedown on a line of credit. Therefore, we will treat a negative balance on a demand deposit as a takedown of an unsecured line of credit.

\subsection{Results}

In Table 1A, we describe the kinds of loans that each type of institution makes to small firms. Approximately $70 \%$ of banks' lending is through lines of credit, with $31 \%$ coming from unsecured lines of 
credit. An unsecured line may be the closest analog to the concept in our model, since it does not require the borrower to arrange for collateral to cover the loan, and hence may be more unpredictable in its drawdown behavior than a secured line. By comparison, only $51 \%$ of finance company lending is through lines of credit, and hardly any of these-just 5\%-are unsecured lines. Interestingly, insurance companies also offer unsecured lines of credit, perhaps because some of them maintain substantial amounts of liquid assets. No other type of institution offers significant amounts of unsecured credit lines.

Table 1B describes the sourcing of loans from the firms' point of view. Over 95\% of unsecured lines of credit come from banks, as well as $81 \%$ of secured lines of credit. All other sources account for only a miniscule proportion of the lines of credit taken down by small firms.

Finally, the database also contains responses to the following questions: "Has your firm ever required financing for seasonal or unexpected short term credit needs? If so, to what source does the firm first look for financing these needs?" Over $70 \%$ of respondents mentioned a bank as the primary source for this type of credit. Approximately $1 \%$ mentioned a finance company, while a fraction of a percent mentioned an insurance company. The most important source other than banks was family and friends.

In summary then, the evidence from the NSSBF suggests that banks are the most important source that (small) firms use to fund unexpected credit needs. Also, the lines of credit through which banks fund these needs account for the major part of bank lending.

\section{Within-Banking-Sector Tests}

Next, we look across a sample of banks to see if the model accurately describes the structure of their lending, deposit-taking and liquid-asset holdings. To get started we must identify the three empirical counterparts to these variables. We must also determine the time horizon over which to measure our indicators and the set of banks to be used in our analysis. We begin by discussing these choices and describing the basic characteristics of the data. 


\subsection{Measuring Deposits, Liquid Assets and Commitments}

The underlying data source for this analysis are the regulatory filings that all commercial banks having insured deposits submit each quarter. These filings, commonly referred to as the "Call Reports", include detailed information on the composition of bank balance sheets and some additional data on the banks' off-balance sheet items. Thus much of the data work involves making judgements about which of the hundreds of variables in the Call Report to study.

Relative to the measurement issues involving lending and deposits, the choices concerning liquidasset holdings $-S_{0}$ in our model-are relatively straightforward. The Call Reports identify three categories of assets that could serve the buffer-stocking role hypothesized for $S_{0}$. The most obvious of these assets is cash. Cash clearly fits the bill, since it not only is held for precautionary purposes, but also pays no interest and therefore is expensive for banks to hold.

However, both the spirit of the model and common sense suggest that banks could also hold securities for buffer-stocking. As mentioned earlier, one can appeal to tax or agency considerations to justify the cost of holding securities that is assumed in the model. The Call Report distinguishes between two sets of securities, those which are expected to be held to maturity and those which are available for sale. These distinctions are made so that the banks can mark their trading portfolio to market while leaving the non-trading securities on balance sheet at book value. For our purposes these distinctions are probably irrelevant, since in a pinch either can be sold off to raise funds. Thus, we also consider a second proxy for $S_{0}$ that includes the sum of cash plus the two securities variables.

In order to focus on the dimensions of the data emphasized by our model, we would like to normalize all of our proxies to remove pure scale effects. For securities, the natural scaling is to normalize by assets. ${ }^{19}$ Thus, we define our empirical counterpart to $S_{0}$ to be either: i) the ratio of cash to assets,

\footnotetext{
19 Alternatively, one might also want to include any loan commitments that are in-place but not yet exercised in the denominator. We explored this possibility and found that normalizing by either total assets or total assets
} 
which we call CASHRAT; or ii) the sum of cash and the two securities measures divided by total assets, which we call SECRAT.

Deciding on a proxy for loan commitments requires more judgement. Ideally we seek to isolate the credit that has been extended by the bank which can be draw down upon demand by borrowers. However, the model also presumes that these withdrawals should be somewhat unpredictable so that they generate a liquidity management problem for the bank.

The Call Reports identify three types of obligations which potentially fit this description. A feature that is common to all three of these variables is that the Call Reports only measure the level of unused commitments. As we discuss below, this method of measuring commitments can potentially cause problems for our tests and will require us to consider explanations beyond those suggested by our theoretical model for some of the correlations that we uncover.

The first set of obligations that could be included are standard loan commitments. The borrowers for these commitments range from consumers (through home equity loans), to construction firms (through real estate commitments and construction and development commitments), to other businesses (through commercial letters of credit, securities underwriting commitments, and "other commitments" which are mainly obligations to supply loans to commercial and industrial firms). ${ }^{20}$ These conventional commitments clearly fit the notion of liquidity provision embodied in the model. ${ }^{21}$

The second set of obligations to be considered are credit card commitments. Not surprisingly, in

plus loan commitments gives virtually identical results

${ }^{20}$ According to the instructions to the Call Report, a commercial letter of credit is issued to specifically facilitate trade or commerce and is typically "drawn when the underlying transaction is completed." (Instructions to the Call Reports 9/97, page A54.) A loan commitment "involves an obligation (with or without a material change or similar clause) to fund its customer in the normal course of business should the customer seek to draw down the commitment. (Page 3.866 of Transmittal 192 of the Federal Reserve Regulatory System (2/97) manual.)

${ }^{21}$ See Shockley and Thakor (1997) for a detailed analysis of the contractural structure of loan commitments. 
aggregate, the unused line limits associated with credit cards are large, equal to roughly the amount of all the other loan commitments in the first category. ${ }^{22}$ However, we have both practical and conceptual concerns with lumping in unused balances on credit cards with the aforementioned types of commitments.

Conceptually, we worry that a significant amount of the unused credit card limits are extremely unlikely to be drawn upon. For instance, a significant fraction of credit card customers pay their balances in full each month. These customers often have the highest limits even though they are perhaps the least likely customers to carry any balances. Thus, a bank is likely to have a noticeably lower probability of having its credit card commitments tapped than the other types of commitments described above. This implies that the liquidity provision offered through credit cards may be very different than that offered by conventional commitments. Treating the two types of commitments equally by adding them together would ignore this distinction.

A further practical problem is that the issuance of credit cards is dominated by a relatively small number of banks. For instance, as of the second quarter of 1995, 78 percent of all credit card balances outstanding reflected cards issued by the top 25 banks. This fact means that accurately modelling the credit card business really boils down to understanding the behavior of fewer than 100 of the $6000+$ banks that were issuing cards in the early 1990s.

This concentration is somewhat of a mixed blessing. On the one hand, it means that the vast majority of banks have relatively little credit card exposure. This in turn suggests that the difference between conventional commitments and credit card commitments may not matter too much for the type of "equal-weighted" regressions that we run. Indeed, it is not surprising that our major findings hardly change if we do lump together credit card commitments and conventional commitments. On the other hand, we doubt that our model captures many of the factors governing card issuance at the leading credit card banks.

\footnotetext{
${ }^{22}$ For instance, as of the end of 1995 the ratio of credit card commitments to the sum of credit card commitments and all other types of commitments was 0.516 .
} 
To avoid having to fully model this somewhat separate line of business we opt to exclude credit card commitments from our baseline definition of commitments.

Similarly, our baseline proxy for commitments also excludes a third type of commitment-like obligations: standby-letters-of-credit (SLOCs). The regulatory guidelines indicate that SLOCs are distinguished from other letters of credit and loan commitments because of "the combination of irrevocability with the fact that the funding is triggered by some failure to repay or perform some obligation". This wording suggests that-counter to the spirit of our model-a bank is likely to have some warning that it may be called upon to provide funding with an SLOC, if, e.g., it can predict when a client is approaching financial distress. As a practical matter, these subtleties are unlikely to matter much, because the aggregate volume of SLOCs is quite small relative to other forms of commitments. ${ }^{23}$

Having settled on a measure of commitments, we again need a way to purge it of pure size effects. In doing so, we also want to avoid co-mingling the lending decision with the liquid-assets-holding decision. This desire to abstract from capital structure considerations means that we cannot use assets as our denominator. Instead, we isolate the structure of banks' lending by looking at the ratio of credit extended through commitments relative to standard term-lending. To do this and to minimize the impact of any outliers we use the ratio of conventional commitments over the sum of commitments plus loans as our proxy, and call this variable COMRAT.

The construction of our deposit proxy raises many of the same considerations as the commitment proxy. Specifically, we need to decide which of the various types of deposits identified in the Call Reports are most similar to the variable $D_{0}$ in the model. We also need to find a scaling procedure that eliminates size effects in a sensible way.

${ }^{23}$ For instance, at the end of 1995 for all banks the ratio of net performance SLOC plus net financial SLOC to total commitments (including credit cards) plus all net LOCs is about 7.1 percent. Also the SLOCs seem to be much more prevalent amongst large banks. 
Historically one might have been able to use what the Call Reports label "demand deposits" (defined as non-interest bearing deposits which are payable on demand) as a clean measure of $D_{0}$. Clearly these deposits (which as of 1995 still accounted for about $21.5 \%$ of all deposits) fit with the concept described in the model. However, over the last 20 years a number of other accounts have emerged which provide transactions services while paying some interest to depositors. In this case, the regulations embedded in the Call Reports offer a convenient classification scheme since all accounts that can be used for transactions purposes are aggregated into a single category called "transactions deposits". We use transaction deposits in the numerator of our deposit proxy.

In focusing on transactions deposits we are excluding certain types of deposits which may be accessible on demand but subject to certain limitations. For instance, a money market deposit account restricts the holder to writing no more than 3 checks per month but typically offers a return very close to the treasury bill rate. We felt that this type of account was more akin to a savings-type account than the ones described in our model. However, in unreported sensitivity checks, we find that using a broader measure that includes both money market deposit accounts and transactions accounts makes no difference to our main results.

To normalize our deposit proxy, we could in principle scale by a variety of measures of bank

liabilities. We opt to use total deposits as our baseline denominator. Thus our empirical deposit variable, which we call DEPRAT, is the ratio of transactions deposits to total deposits. We have also experimented with using narrower measures-such as the sum of transactions deposits and time and savings accounts-in the denominator of this ratio, and find that this makes relatively little difference to our results.

\subsection{Sample Formation}

Given these three proxies for commitments, securities and deposits we next need to settle on a rule for selecting a sample of banks and the time period over which to measure the data. Our biggest concern is 
to avoid inadvertently generating any spurious correlations amongst our proxies because of sample selection.

This suggests that we want to minimize the number of banks that are dropped from the sample. Therefore, we do not condition on whether banks are continuously in our sample or whether they engaged in mergers. (Fortunately, it turns out that screening on these criteria does not change any of our principal findings.) Thus, in what follows, the results pertain to a sample where the only condition for inclusion is that a bank has at least two years of data during the period between 1992 and 1996.

We collect data over this five-year window because we believe that having some time-series data helps us to address a potential econometric problem. This problem arises because the commitment data from the Call Reports capture the actual volume of unused commitments. At high frequencies, this may differ from the concept in our model, which is, roughly speaking, the bank's target level of unused commitments. Consider the following example of how things might go awry econometrically. Suppose that a small bank has as one of its major customers a local builder, who is both a depositor and a commitment borrower. Now imagine that this builder experiences a liquidity shock. In an effort to cope, he drains his checking account-thereby reducing transactions deposits-and also draws down his line of credit. Given the way things are measured, this will show up as a reduction in commitments, and we may spuriously estimate a positive correlation between transactions deposits and commitments that is not due to the liquidity synergy that we hypothesize, but rather to high-frequency liquidity-demand shocks.

Having several years' worth of data helps us to address this concern in a number of ways. Our first, most basic approach is to time-average the bank-level data. By averaging across several years we remove any high-frequency variation in liquidity demand that might be generating the sort of mechanical correlation just described. Intuitively, over a period of several years, a bank's average observed level of ununsed commitments should closely approximate its target level of unused commitments. So our baseline sample uses the average values of all of our proxies over the last five years for which complete data is 
available. As an aside, the particular five year interval we use (1992-1996) also has the advantage of excluding any business cycle turning points and having had the Basle risk-based capital standards fully-inplace. $^{24}$

In addition to the time-averaging, we have in unreported robustness tests investigated two other alternatives that draw on the panel structure of the data to assess the importance of high-frequency shifts in liquidity demand. One set of tests involves running panel regressions to see if any correlations increase when we just pool all the data without doing the time-averaging. It turns out that the correlations in the raw, unaveraged data are if anything slightly weaker than those we report below, suggesting that spurious hardwiring due to high-frequency liquidity shocks is not very important.

As another alternative to time-averaging we have also conducted instrumental variables estimation in which the lagged (four or eight quarters) value of DEPRAT is used to instrument for the current value. The results are very similar to those shown below. This also suggests that the results are driven by the permanent across-bank variation in the data, and not by high-frequency within-bank variation in liquidity demand. To conserve on space in what follows we only report results for the time-averaged data.

\subsection{Descriptive Statistics}

Table 2 shows information on our principal variables, COMRAT, DEPRAT, CASHRAT, and SECRAT, for both the entire sample of banks and for three sub-categories of banks based on the size of average assets. The data reveal several noteworthy patterns. First, even though all the variables are already scaled, there are still striking differences across bank size for commitments and liquid assets. For

\footnotetext{
${ }^{24}$ For banks with less than five years of data we use all the available observations to form the averages. However, the results from analyzing a sample where only banks with five full years of data are available and the banks have not undergone any significant mergers (defined as acquiring another bank with more than $10 \%$ of the acquiring bank's assets) are very similar to those shown below.
} 
instance, the median value of COMRAT for the banks in the top one percent of the size distribution is 0.282, as opposed to 0.081 for the smallest banks. This implies that the typical large bank has more than three times as much of its loan portfolio pledged towards commitments than the typical small bank. On the other hand, as is well-known, small banks are much more likely to hold securities. Perhaps more surprising is the observation that large banks tend to hold more in cash (relative to assets) than smaller banks. Lastly, the table shows that there is considerable variation in DEPRAT within each sub-sample, but no clear correlation for this measure with bank size.

\subsection{Regression Results}

Having established the basic properties of the data we now present some evidence regarding our two within-banking-sector predictions. Given the overwhelming importance of bank size documented in Table 2, we take two steps to control for size. First, we conduct the analysis for both the full sample and separately for each of the size-based sub-samples. Secondly, we also control for size within each sample by including the log of real bank assets in all of our regressions.

Finally the regression results shown in the subsequent tables also include a set of regional dummy variables (for each Federal Reserve District), and information on the composition of each bank's loan portfolio (specifically: the ratio of commercial and industrial loans to total loans; the ratio of real estate loans to total loans; and the ratio of loans to individuals to total loans.) We view the loan composition and regional dummies as further attempts to soak up variation in customer liquidity demand-in this case, across-bank variation-that might be problematic. More specifically, these proxies should help control for any latent patterns in the propensity of different types of borrowers to have simultaneously greater demand for both transactions deposits and commitments. This helps counter an objection of the following sort: "Bank $X$ has high levels of both transactions deposits and commitments not because of any liquidity synergy, but rather because it caters to a particular type of client base that likes both of these products." 
An extreme version of this concern is the possibility that, in the cross-section, a correlation between transactions deposits and loan commitments might be induced mechanically by compensating balance arrangements, whereby commitment users are required to hold some money in a checking account with the bank providing the commitment. While we cannot get at this possibility directly with the Call Report data, we can provide some comfort from two other sources. First, Berger and Udell (1995) show that loan commitments only rarely (in $7 \%$ of the contracts they examine) involve compensating balance agreements. Second, from the NSSBF, we obtained data on both the total unused lines of credit each firm has, as well as its total deposits. A cross-sectional regression of the former against the latter produces a coefficient that is both statistically and economically indistinguishable from zero.

\subsection{A. Prediction 2: Commitments vs. Transactions Deposits}

Table 3 reports the results of regressing COMRAT on DEPRAT. These regressions test the first, and most basic prediction of our theory: namely, that commitment intensity and transactions deposit intensity should be positively correlated. The table shows that there is indeed a very strong positive correlation. The pattern holds within each size category of banks and is most statistically significant, with a t-stat of 21.04, for the small banks (although this difference in significance appears to be due to the huge number of small banks, rather than to any systematic difference in the point estimates). As mentioned earlier, these results do not depend on the particular proxies used for deposits and commitments. For instance, neither including credit cards in the definition of commitments nor adding money market deposit accounts to the numerator of our deposit proxy noticeably changes the results. Similarly, if one narrows the deposit numerator to be just demand deposits, we again get very similar results. The one qualification that we uncover in these various robustness checks is that the coefficient estimates for the large and medium banks are not always statistically significant. Thus, our interpretation of the data is that there is at a minimum a very robust positive correlation between transactions deposits and commitments for the vast 
majority of banks.

\subsection{B. Prediction 3: Commitments vs. Liquid Assets with Deposits as an Instrument}

Next we attempt to test Prediction 3, which holds that the correlation between commitments and transactions deposits seen in Table 3 is present specifically because of a synergy working through liquidasset holdings. This is clearly a sharper test of our theory. As a first step in this direction we confirm that the presence of transactions deposits leads banks to hold additional liquid assets. As mentioned above, one might use either just cash (CASHRAT) or cash plus securities (SECRAT) as a proxy for liquid assets. Table 4 shows the results for both types of regressions. CASHRAT and DEPRAT are strongly positively correlated across all size categories of banks. This is hardly surprising, since both reserve requirements and the presence of automatic-teller machines will induce this sort of correlation.

Once the definition of liquid assets is expanded to include cash and securities (SECRAT), the correlations drop noticeably. Interestingly the declines in the coefficients and levels of statistical significance are more pronounced at large and mid-sized banks than at small banks. One interpretation of this finding is that the cash holdings for these bigger banks are sufficient to permit them to do much of the buffer-stocking that is necessary. Whatever the reason for the differences, for the remaining tests we continue to report results using both proxies for liquid assets.

While the results in Table 4 may be a necessary precondition for our theory to be empirically relevant, the heart of the test of Prediction 3 is the IV regression that asks whether commitments are related to those liquid assets which are held to back transactions deposits. In other words, we want to regress commitments (COMRAT) on liquid assets (CASHRAT or SECRAT) and use transactions deposits (DEPRAT) as an instrument for liquid assets. As explained in our discussion of the model in Section 3, instrumenting with transactions deposits is key because the raw correlation between securities and commitments will be determined by multiple factors-e.g., the raw correlation could be negative if there is 
substantial heterogeneity across banks in costs of external finance. And indeed, this is what we see in the data: a simple OLS regression of COMRAT on SECRAT for our full sample of banks uncovers a significant negative correlation. $^{25}$

But strikingly, Table 5 shows that when one instruments with DEPRAT, the correlation between COMRAT and SECRAT switches signs, and is now consistently positive. Moreover, the coefficients are statistically significant for the full sample as well as for the sample of small banks. The results using CASHRAT as the proxy for liquid assets also show the same pattern. We believe the results in Table 5 provide very direct evidence in favor of the synergy predicted by the model. (These results are also robust to using the previously-described alternative proxies for deposits and commitments.)

The economic magnitude of the coefficients does not vary much across banks. Thus, even though it is not obvious what benchmark we should use for quantifying the magnitude of the correlations, they seem to be important for all three size categories.

\section{Conclusions}

Recent research on financial intermediation has remained largely silent on the question of what ties together the traditional commercial banking functions of deposit-taking and lending. Our main point is that in a sense, they are just two different manifestations of the same function-the provision of liquidity on demand. This is especially true to the extent that banks are heavily involved in commitment-based lending. After all, once the decision to extend a line of credit has been made, it is really nothing more than a checking account with overdraft priveleges, or a demand deposit account with a negative balance.

Once it is recognized that loan commitments and demand deposits represent very similar products, it is an easy step to argue that there may be synergies to offering both. In this paper, we have focused on

\footnotetext{
25 For instance, the coefficient on SECRAT for all banks (i.e. the OLS estimate equivalent to the first coefficient shown in panel B of Table 5) is -0.029 and has a t-statistic of 7.22.
} 
developing a theoretical and empirical case for one particular such synergy, namely the sharing of the burden of holding liquid assets on the balance sheet. However, it should be noted that there may a variety of other synergies which operate in a broadly similar manner, with commitments and demand deposits sharing the cost of a common resource that helps in the provision of liquidity.

Consider for example a financial institution facing the choice of whether it should seek to acquire a commercial banking charter, or instead set itself up as some sort of non-bank intermediary, such as a finance company. On the one hand, there are clearly a variety of costs associated with being a commercial bank-one has to submit to all sorts of additional regulation and supervision, capital requirements, reserve requirements, etc. On the other hand, one gains access to such valuable government-provided services as the Federal Reserve's discount window, as well as the payments system, with the associated large daylight overdraft priveleges. If an institution is going to bear the costs, it will obviously be better off to the extent that these costs can be spread over not just a deposit-taking franchise, but any other activities that can also take advantage of things like the discount window and access to the payments system. Again, lending on a commitment basis would seem to fit this description perfectly.

From a policy perspective, our work suggests that the resilience of the institutional form of the commercial bank may be attributable to real considerations of economic efficiency that have hitherto been ignored, rather than simply to historical accident or the distortions inherent in policies such as deposit insurance. Therefore calls for narrow banking-which are typically premised on the idea that deposit-taking and lending are two totally different and unrelated activities-may be leaving out an important consideration.

More generally, this paper points to the merits, as well as the potential pitfalls, of the functional approach to financial regulation advocated by Merton (1995). On the positive side, few economists would quarrel with the eminently reasonable idea that regulators should look at the underlying function that a financial product provides, rather than its nomenclature. The danger arises if one defines the functions too 
narrowly, and therefore fails to see the complementarities between closely related activities. For example, since there are some institutions (like money market funds) that specialize in an activity much like deposittaking, and others (like finance companies) that specialize in lending, an overly simplistic application of the functional logic might lead one to claim that there is nothing really unique about the institutional form of commercial banking-i.e., what commercial banks do is spanned by other types of intermediaries. This in turn might be used to argue there is no need for regulation to be tailored in any way to the particulars of the commercial banking industry; e.g., the lending side of a bank might be thought of and treated as functionally indistinguishable from that of a finance company.

In our view, this kind of reasoning misses the key point that bank lending is fundamentally different in nature, and is inextricably tied up with banks' deposit-taking activities. If one insists on assigning activities to functional buckets, it may make more sense to stick both commitment-based lending and deposit-taking into a single bucket, and label the function "liquidity provision". According to this definition, banks are not so obviously spanned by other types of intermediaries, and may legitimately deserve to be thought of as a special type of financial institution. 


\section{$\underline{\text { Appendix }}$}

\section{Proof of Proposition 2:}

First, let us derive the optimal commitments and liquid-asset holdings in the various regions. We showed in the text that in Region 1 where $S_{0}{ }^{*}<\operatorname{Min}\left[C^{*}, D_{0}\right]$, we have:

$$
S_{0}{ }^{*}=\left[C^{*}+D_{0}-2(\tau / \alpha)\right] /[2-\rho]
$$

and $C^{*}$ solves:

$$
f+C f_{C}=\alpha /(4-2 \rho) \quad\left[\left(2 \rho-\rho^{2}-1\right) D_{0}+(1-\rho) C+2(\tau / \alpha)\right]
$$

The same basic method of solution can be applied to the other regions, with $e_{1}$ evaluated differently in each case, according to equation (8) in the text. In Region 2 where $C^{*} \leq S_{0}{ }^{*}<D_{0}$, this yields:

$$
S_{0}^{*}=D_{0}+\rho C^{*}-2 \tau / \alpha
$$

and $C^{*}$ solves:

$$
f+C f_{C}=\alpha \rho(1-\rho) C / 2+\rho \tau
$$

In Region 3 where $D_{0} \leq S_{0}{ }^{*}<\mathrm{C}^{*}$ we obtain:

$$
S_{0}{ }^{*}=\rho D_{0}+C^{*}-2 \tau / \alpha
$$


and $C^{*}$ solves:

$$
f+C f_{C}=\tau
$$

In Region 4 where $S_{0}{ }^{*} \geq \operatorname{Max}\left[C^{*}, D_{0}\right]$, we have:

$$
S_{0}^{*}=D_{0}+C^{*}-2 \tau / \alpha \rho
$$

and $C^{*}$ solves:

$$
f+C f_{C}=\tau
$$

We now trace how $C^{*}$ and $S_{0}{ }^{*}$ move with $D_{0}$. Start with $D_{0}=0$. Since $S_{0}{ }^{*} \geq 0$, we must be in Region 3 or Region 4. However, we cannot be in Region 4 because (A.7) would imply that $S_{0}{ }^{*}<C^{*}$ when $D_{0}=0$, which is incompatible with being in Region 4. Therefore, we start in Region 3. Let us assume continuity of $S_{0}{ }^{*}$ and $C^{*}$ in $D_{0}$ in what follows. We will verify this assumption later.

Let $C^{\tau}$ be the value of $C$ that solves (A.6). Then $C^{*}=C^{\tau}$ in the region. As a result, $d S_{0}{ }^{*} / d D_{0}=\rho<1$ in Region 3. This implies that either $D_{0}$ will eventually hit $S_{0}{ }^{*}$ (and we will move to Region 1 ) or $S_{0}{ }^{*}$ will hit $C^{\tau}$ (and we will move to Region 4). Substituting $S_{0}{ }^{*}$ for $D_{0}$ in (A.5), solving for $S_{0}{ }^{*}$, and recognizing that $S_{0}{ }^{*}<C^{\tau}$ in Region 3, we get the necessary condition to move into Region 1 as $C^{\tau}<2 \tau / \alpha$. By contrast, if $C^{\tau}>2 \tau / \alpha$, it is easily shown that $S_{0}{ }^{*}$ will eventually hit $C^{\tau}$ and we move to Region 4 . So we have two cases to examine.

Case 1: $C^{\tau}>2 \tau / \alpha$ 
Let us quickly describe what happens in Region 4. $C^{*}$ does not vary with $D_{0}$, and has constant value $C^{\tau}$. Therefore, $d S_{0}{ }^{*} / d D_{0}=1$. This implies that we will not leave Region 4 since liquid assets are greater than deposits and commitments to begin with, and while commitments do not change with $D_{0}$, liquid assets grow one for one with it. Thus liquid assets will always be greater than deposits and commitments and we will not leave Region 4 however high the level of deposits. So if $C^{\tau}>2 \tau / \alpha$, we move from Region 3 to Region 4. Commitments are invariant with deposits in both regions.

Case 2: $C^{\tau}<2 \tau / \alpha$

In this case, we move from Region 3 to Region 1. Totally differentiating (A.1), we get:

$$
\frac{d S_{0}^{*}}{d D_{0}}=\frac{1}{2-\rho}\left(1+\frac{d C^{*}}{d D_{0}}\right)
$$

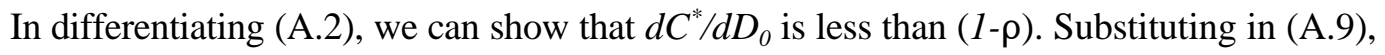
$d S_{0}{ }^{*} / d D_{0}<1$. So we do not move to a region where $S_{0}{ }^{*}>D_{0}$. We can only move to Region 2 . In Region 2 , $d C^{*} / d D_{0}=0$. Therefore, $d S_{0}{ }^{*} / d D_{0}=1$. So $S_{0}{ }^{*}$ will continue to be below $D_{0}$ as $D_{0}$ increases, while $S_{0}{ }^{*}$ will continue to be above $C^{*}$ as $D_{0}$ increases. So we will never leave the region.

Having determined the regions we move between as $D_{0}$ increases, we now have to show that commitments and holdings of liquid assets are (weakly) increasing in $D_{0}$. We know $S_{0}{ }^{*}$ and $C^{*}$ are weakly increasing in $D_{0}$ in each region. To show that they (weakly) increase throughout, we have to show that they are continuous in $D_{0}$. Clearly, they are continuous within a region. We now show that they are continuous as they transit between regions.

Let us consider the transition between Region 3 and Region 1; the other transitions are similar. 
Consider Region 3. Let the value of $D_{0}$ at which $S_{0}{ }^{*}=D_{0}$ be $D^{\tau}$. Substituting for $S_{0}{ }^{*}$ in (A.5) and solving, we get:

$$
D^{\tau}=C^{\tau} /(1-\rho)-2 \tau /[\alpha(1-\rho)]
$$

and this is also the value of $S_{0}{ }^{*}$. We know the value of $C^{*}=C^{\tau}$. These are the left hand limits of the functions $S_{0}{ }^{*}$ and $C^{*}$ as $D_{0}$ increases to the boundary between the regions. To show the functions $S_{0}{ }^{*}$ and $C^{*}$ are continuous, we have to show the right hand limits are the same.

In Region $1, S_{0}{ }^{*}$ is described by (A.1). Substituting $D^{\tau}$ as described in (A.10) for $D_{0}$ and simplifying, we get

$$
S_{0}^{*}=\frac{C^{*}(1-\rho)+C^{\tau}}{(2-\rho)(1-\rho)}-\frac{2 \tau}{\alpha(1-\rho)}
$$

Substituting $D^{\tau}$ as described in (A.10) for $D_{0}$ and $S_{0}{ }^{*}$ as described by (A.11) into (A.2), $C^{*}$ is obtained by solving:

$$
f+C^{*} f_{C}=\frac{\alpha}{2}\left[\frac{(1-\rho)^{2}\left(C^{*}-C^{\tau}\right)}{(1-\rho)(2-\rho)}\right]+\tau
$$

Clearly $C^{\tau}$ solves this. As a result, the right hand limit of $C^{*}=C^{\tau}$. Substituting in (A.11), we get that the right hand limit of $S_{0}{ }^{*}$ is $C^{\tau} /(1-\rho)-2 \tau /[\alpha(1-\rho)]$. Therefore the right hand limits equal the left hand limits and $C^{*}$ and $S_{0}{ }^{*}$ are continuous in $D_{0}$ at the boundary between regions. It is a tedious but straightforward task to show continuity across the other borders also. Thus $S_{0}{ }^{*}$ and $C^{*}$ are weakly increasing in $D_{0}$ throughout. Q.E.D. 


\section{$\underline{\text { References }}$}

Bernanke, Ben S., and Alan S. Blinder 1988. "Credit, Money and Aggregate Demand," American Economic Review 78: 435-439.

Bernanke, Ben S., and Alan S.Blinder 1992. "The Federal Funds Rate and the Channels of Monetary Transmission," American Economic Review 82: 901-921.

Berger, Allen and Gregory Udell 1995. "Lines of Credit and Relationship Lending in Small Firm Finance," Journal of Business 68: 351-381.

Bryan, Lowell 1988. Breaking Up The Bank : Rethinking an Industry Under Siege Dow Jones-Irwin, Homewood, IL.

Calomiris, Charles and Charles Kahn 1991. "The Role of Demandable Debt in Structuring Optimal Banking Arrangements,” American Economic Review 81: 497-513.

Cosimano, Thomas and Bill McDonald 1998. "What's Different Among Banks?” Journal of Monetary Economics 41: 57-70.

De Roover, R. 1948. Money, Banking, and Credit in Medieval Bruges Medieval Academy of America Cambridge, MA.

Diamond, Douglas 1984. "Financial Intermediation and Delegated Monitoring," Review of Economic Studies 51: 393-414.

Diamond, Douglas and Philip Dybvig 1983. "Bank Runs, Deposit Insurance, and Liquidity," Journal of Political Economy 91: 401-419.

Diamond, Douglas and Raghuram Rajan 1998. "Liquidity Risk, Liquidity Creation and Financial Fragility: A Theory of Banking," working paper, University of Chicago.

Flannery, Mark J. 1994. "Debt Maturity and the Deadweight Cost of Leverage: Optimally Financing Banking Firms,” American Economic Review 84: 320-331.

Froot, Kenneth and Jeremy Stein 1998. "Risk Management, Capital Budgeting, and Capital Structure Policy for Financial Institutions: An Integrated Approach," Journal of Financial Economics 47: $55-82$.

Gorton, Gary, and George Pennacchi 1990. "Financial Intermediaries and Liquidity Creation," Journal of Finance 45: 49-71.

Gorton, Gary and George Pennacchi 1992. "Financial Innovation and the Provision of Liqudity Services," in Reform of Federal Deposit Insurance edited by James Barth and Dan Brumbaugh, Harper Collins. 
Hammond, Bray 1957. Banks and Politics in America Princeton University Press Princeton, NJ.

Hannan, T. 1991. "Bank Commercial Loan Markets and the Role of Market Structure: Evidence from Surveys of Commercial Lending," Journal of Banking and Finance 15: 133-149.

Holmstrom, Bengt and Jean Tirole 1997. "LAPM: A Liquidity-based Asset Pricing Model," working paper, Massachusetts Institute of Technology.

Holmstrom, Bengt and Jean Tirole 1998. "Public and Private Supply of Liquidity," Journal of Political Economy 106:1-40.

Kashyap, Anil K., and Jeremy C. Stein 1994. "Monetary Policy and Bank Lending," in Monetary Policy edited by N. Gregory Mankiw, University of Chicago Press, Chicago.

Kashyap, Anil K., and Jeremy C. Stein 1998. "What Do a Million Observations on Banks Have to Say About the Transmission of Monetary Policy?," working paper, Massachusetts Institute of Technology and University of Chicago.

Kashyap, Anil K, Jeremy C. Stein and David W. Wilcox 1993. "Monetary Policy and Credit Conditions: Evidence from the Composition of External Finance," American Economic Review 83: 78-98.

Kishan, Ruby P. and Timothy P. Opiela 1998. "Bank Size, Bank Capital, and the Bank Lending Channel," working paper, Southwest Texas State University.

Lane, F. and R. Mueller 1985. Money and Banking in Mediaeval and Renaissance Venice Johns Hopkins University Press, Baltimore, MD.

Litan, Robert G. 1988. What Should Banks Do? Washington D.C. Brookings Institute.

Ludvigson, Sydney 1998. "The Channel of Monetary Transmission to Demand: Evidence from the Market for Automobile Credit," Journal of Money, Credit and Banking 30: 365-383.

Merton, Robert 1995."Financial Innovation and the Management and Regulation of Financial Institutions," Journal of Banking and Finance 19: 461-482.

Morgan 1998. "The Credit Effects of Monetary Policy: Evidence Using Loan Commitments," Journal of Money, Credit and Banking 30: 102-118.

Myers, Stewart C. 1984. “The Capital Structure Puzzle,” Journal of Finance 39: 575-592.

Myers, Stewart and Raghuram Rajan 1998. "The Paradox of Liquidity,” forthcoming, Quarterly Journal of Economics.

Qi, Jianping 1998. "Deposit Liquidity and Bank Monitoring," forthcoming, Journal of Financial Intermediation. 
Shockley, Richard L. and Anjan V. Thakor 1997. "Bank Loan Commitment Contracts: Data, Theory and Tests," Journal of Money, Credit and Banking 29: 517-534.

Simons, Henry 1948. Economic Policy for a Free Society University of Chicago Press Chicago, IL.

Stein, Jeremy C. 1998. "An Adverse Selection Model of Bank Asset and Liability Management with Implications for the Transmission of Monetary Policy," RAND Journal of Economics 29: 466-486.

Usher, A. 1943. The Early History of Deposit Banking in Mediterranean Europe Harvard University Press, Cambridge, MA. 
Table $1 \mathrm{~A}$

Fraction of each institution' s lending accounted for by loan type (by dollar volume)

\begin{tabular}{l|cccccccc}
\hline & $\begin{array}{c}\text { Unsecured } \\
\text { Lines of } \\
\text { Credit }\end{array}$ & $\begin{array}{c}\text { Secured } \\
\text { Lines of } \\
\text { Credit }\end{array}$ & $\begin{array}{c}\text { Total } \\
\text { Lines of } \\
\text { Credit }\end{array}$ & Leases & Mortgages & $\begin{array}{c}\text { Auto } \\
\text { Loans }\end{array}$ & $\begin{array}{c}\text { Equipment } \\
\text { Loans }\end{array}$ & Other \\
\hline $\begin{array}{l}\text { Commercial } \\
\text { banks/S\&Ls }\end{array}$ & 0.31 & 0.39 & 0.70 & 0.02 & 0.13 & 0.01 & 0.06 & 0.07 \\
$\begin{array}{l}\text { Finance/Leasing } \\
\text { Company }\end{array}$ & 0.05 & 0.45 & 0.51 & 0.15 & 0.08 & 0.10 & 0.11 & .006 \\
$\begin{array}{l}\text { Insurance Company } \\
\text { Brokerage Firm }\end{array}$ & 0.11 & 0.05 & 0.16 & 0.00 & 0.51 & 0.00 & 0.00 & 0.31 \\
Mortgage Bank & 0.01 & 0.12 & 0.13 & 0.00 & 0.65 & 0.00 & 0.00 & 0.22 \\
Venture Capitalist & 0.00 & 0.00 & 0.00 & 0.00 & 0.98 & 0.00 & 0.00 & 0.02 \\
Other & 0.00 & 0.03 & 0.03 & 0.00 & 0.01 & 0.00 & 0.00 & 0.95 \\
\hline
\end{tabular}

Table 1B

Fraction of loan type coming from each institution (by dollar volume)

\begin{tabular}{|c|c|c|c|c|c|c|c|}
\hline & $\begin{array}{l}\text { Unsecured } \\
\text { Lines of } \\
\text { Credit }\end{array}$ & $\begin{array}{c}\text { Secured } \\
\text { Lines of } \\
\text { Credit }\end{array}$ & Leases & Mortgages & $\begin{array}{l}\text { Auto } \\
\text { Loans }\end{array}$ & $\begin{array}{l}\text { Equipment } \\
\text { Loans }\end{array}$ & Other \\
\hline $\begin{array}{l}\text { Commercial } \\
\text { banks/S\&Ls }\end{array}$ & 0.95 & 0.81 & 0.37 & 0.59 & 0.41 & 0.68 & 0.45 \\
\hline $\begin{array}{l}\text { Finance/Leasing } \\
\text { Company }\end{array}$ & 0.03 & 0.17 & 0.55 & 0.05 & 0.56 & 0.23 & 0.06 \\
\hline Insurance Company & 0.02 & 0.00 & 0.00 & 0.11 & 0.00 & 0.00 & 0.09 \\
\hline Brokerage Firm & 0.00 & 0.01 & 0.00 & 0.07 & 0.00 & 0.00 & 0.03 \\
\hline Mortgage Bank & 0.00 & 0.00 & 0.00 & 0.01 & 0.00 & 0.00 & 0.00 \\
\hline Venture Capitalist & 0.00 & 0.00 & 0.00 & 0.00 & 0.00 & 0.00 & 0.08 \\
\hline Other & 0.00 & 0.00 & 0.07 & 0.15 & 0.03 & 0.09 & 0.29 \\
\hline
\end{tabular}




\section{Table 2}

Basic Descriptive Statistics for Deposits, Liquid Assets, and Commitments

The sample includes all federally insured banks that report at least 8 quarters of data between 1992 and 1996. Size categories are based on sorting by the average level of real total assets. Largest banks are the banks whose average real assets are above the 99 percentile of the distribution. The medium-sized banks are those with real assets above the 95th percentile but below the 99th percentile. Small banks are the remaining banks.

Definitions of other variables are contained in the text. Q1 indicates the first quartile, Med. refers to the median, and Q3 denotes the third quartile.

\begin{tabular}{||l|c|c|c|c|c|c|c|c|c|c|c|c||}
\hline \hline & \multicolumn{3}{|c|}{$\begin{array}{c}\text { All Banks } \\
(\mathrm{N}=12,367)\end{array}$} & \multicolumn{3}{c|}{$\begin{array}{c}\text { Large Banks } \\
(\mathrm{N}=124)\end{array}$} & \multicolumn{3}{c||}{$\begin{array}{c}\text { Medium-Sized Banks } \\
\text { (N=493) }\end{array}$} & \multicolumn{3}{c||}{$\begin{array}{c}\text { Small Banks } \\
(\mathrm{N}=11,750)\end{array}$} \\
\hline $\begin{array}{l}\text { 1992-1996 Time- } \\
\text { Averaged Data: }\end{array}$ & Q1 & Med. & Q3 & Q1 & Med. & Q3 & Q1 & Med. & Q3 & Q1 & Med. & Q3 \\
\hline $\begin{array}{l}\text { Cash/ } \\
\text { Assets: CASHRAT }\end{array}$ & 0.035 & 0.047 & 0.066 & 0.056 & 0.075 & 0.124 & 0.032 & 0.055 & 0.084 & 0.035 & 0.047 & 0.065 \\
\hline $\begin{array}{l}\text { Cash+Securities/ } \\
\text { Assets: SECRAT }\end{array}$ & 0.263 & 0.348 & 0.457 & 0.235 & 0.270 & 0.348 & 0.189 & 0.289 & 0.384 & 0.266 & 0.352 & 0.460 \\
\hline $\begin{array}{l}\text { Trans. Deposits/ } \\
\text { Total Deposits: } \\
\text { DEPRAT }\end{array}$ & 0.225 & 0.282 & 0.346 & 0.248 & 0.292 & 0.351 & 0.184 & 0.288 & 0.348 & 0.225 & 0.282 & 0.345 \\
\hline $\begin{array}{l}\text { Commitments/ } \\
\text { Commit.+Loans): } \\
\text { COMRAT }\end{array}$ & 0.044 & 0.083 & 0.132 & 0.198 & 0.282 & 0.348 & 0.103 & 0.161 & 0.218 & 0.043 & 0.081 & 0.127 \\
\hline
\end{tabular}




\section{Table 3}

\section{Commitments vs. Transactions Deposits}

Dependent variable is COMRAT, the ratio of loan commitments to loan commitments plus loans. The sample includes all federally insured banks that report at least 8 quarters of data between 1992 and 1996. Size categories are based on sorting by the average level of real total assets. Largest banks are the banks whose average real assets are above the 99 percentile of the distribution. The medium-sized banks are those with real assets above the 95th percentile but below the 99th percentile. Small banks are the remaining banks. Coefficient and t-statistics are shown for the coefficient on DEPRAT, the ratio of transactions deposits to total deposits. The other independent variables whose coefficients are not reported in the table are listed in the text.

\begin{tabular}{||l|c|c|c|c||}
\hline & \multicolumn{4}{|c||}{ Sample } \\
\hline & All Banks & Large Banks & $\begin{array}{l}\text { Medium-Sized } \\
\text { Banks }\end{array}$ & Small Banks \\
\hline Number of observations & 12367 & 124 & 493 & 11,750 \\
\hline $\begin{array}{l}\text { Coefficient on DEPRAT: } \\
\text { Transaction Deposits/Total Deposits }\end{array}$ & 0.111 & 0.180 & 0.074 & 0.113 \\
(T-statistic) & $(20.99)$ & $(2.23)$ & $(2.85)$ & $(21.04)$ \\
\hline
\end{tabular}


Table 4

Liquid Assets vs. Transactions Deposits

Dependent variable in panel A is CASHRAT, the ratio of cash to assets. In panel B the dependent variable is SECRAT, the ratio of cash plus securities to assets. In both panels the sample includes all federally insured banks that report at least 8 quarters of data between 1992 and 1996 . Size categories are based on sorting by the average level of real total assets. Largest banks are the banks whose average real assets are above the 99 percentile of the distribution. The medium-sized banks are those with real assets above the 95th percentile but below the 99th percentile. Small banks are the remaining banks. Coefficient and t-statistics are shown for the coefficient on DEPRAT, the ratio of transactions deposits to total deposits. The other independent variables whose coefficients are not reported in the table are listed in the text.

\begin{tabular}{|c|c|c|c|c|}
\hline & \multicolumn{4}{|c|}{ Sample } \\
\hline & All Banks & Large Banks & $\begin{array}{l}\text { Medium-Sized } \\
\text { Banks }\end{array}$ & Small Banks \\
\hline Number of Observations & 12,367 & 493 & 11,750 & \\
\hline \multicolumn{5}{|c|}{ Panel A: Dependent Variable = CASHRAT: Cash/Assets } \\
\hline $\begin{array}{l}\text { Coefficient on DEPRAT: } \\
\text { Transactions Deposits/Total Deposits } \\
\text { (T-statistic) }\end{array}$ & $\begin{array}{r}0.085 \\
(25.46) \\
\end{array}$ & $\begin{array}{l}0.138 \\
(2.40) \\
\end{array}$ & $\begin{array}{l}0.059 \\
(3.98) \\
\end{array}$ & $\begin{array}{r}0.082 \\
(24.47) \\
\end{array}$ \\
\hline \multicolumn{5}{|c|}{ Panel B: Dependent Variable = SECRAT: $($ Cash + Securities $) /$ Assets } \\
\hline $\begin{array}{l}\text { Coefficient on DEPRAT: } \\
\text { Transaction Deposits/Total Deposits } \\
\text { (T-statistic) }\end{array}$ & $\begin{array}{l}0.098 \\
(7.99) \\
\end{array}$ & $\begin{array}{l}0.082 \\
(0.71) \\
\end{array}$ & $\begin{array}{l}0.028 \\
(0.57) \\
\end{array}$ & $\begin{array}{l}0.105 \\
(8.34) \\
\end{array}$ \\
\hline
\end{tabular}




\section{Table 5}

Commitments vs. Liquid Assets with Transactions Deposits as an Instrument

Dependent variable is COMRAT, the ratio of commitments to loans plus commitments. In panel A the independent variable is CASHRAT, the ratio of cash to assets. In panel B the independent variable is SECRAT, the ratio of cash plus securities to assets. In both panels the sample includes all federally insured banks that report at least 8 quarters of data between 1992 and 1996. Size categories are based on sorting by the average level of real total assets. Largest banks are the banks whose average real assets are above the 99 percentile of the distribution. The medium-sized banks are those with real assets above the 95th percentile but below the 99th percentile. Small banks are the remaining banks. Coefficient and t-statistics are shown for the instrumental variables estimate where DEPRAT, the ratio of transactions deposits to total deposits, is used as the instrument. The other independent variables whose coefficients are not reported in the table are listed in the text.

\begin{tabular}{|c|c|c|c|c|}
\hline & \multicolumn{4}{|c|}{ Sample } \\
\hline & All Banks & Large Banks & $\begin{array}{l}\text { Medium-Sized } \\
\text { Banks }\end{array}$ & Small Banks \\
\hline Number of Observations & 124 & \multicolumn{2}{|c|}{11,750} & \\
\hline \multicolumn{5}{|l|}{ Panel A: Independent Variable = CASHRAT: Cash/Assets } \\
\hline $\begin{array}{l}\text { Coefficient on CASHRAT: Cash/Assets } \\
\text { Instrument: DEPRAT: Transactions Dep./Total } \\
\text { Deposits } \\
\text { (T-statistic) }\end{array}$ & $\begin{array}{c}1.30 \\
(16.79)\end{array}$ & $\begin{array}{c}1.31 \\
(1.87)\end{array}$ & $\begin{array}{c}1.20 \\
(2.34)\end{array}$ & $\begin{array}{c}1.37 \\
(16.40)\end{array}$ \\
\hline \multicolumn{5}{|c|}{ Panel B: Independent Variable = SECRAT: $($ Cash+Securities $) /$ Assets } \\
\hline $\begin{array}{l}\text { Coefficient on SECRAT: (Cash+Securities) /Assets } \\
\text { Instrument: DEPRAT: Transaction Dep./Total } \\
\text { Deposits } \\
\text { (T-statistic) }\end{array}$ & $\begin{array}{r}1.13 \\
(7.27)\end{array}$ & $\begin{array}{r}2.19 \\
(0.70)\end{array}$ & $\begin{array}{r}2.57 \\
(0.56)\end{array}$ & $\begin{array}{r}1.07 \\
(7.49) \\
\end{array}$ \\
\hline
\end{tabular}


Figure 1 A. Relationship between Liquid Assets and Deposits

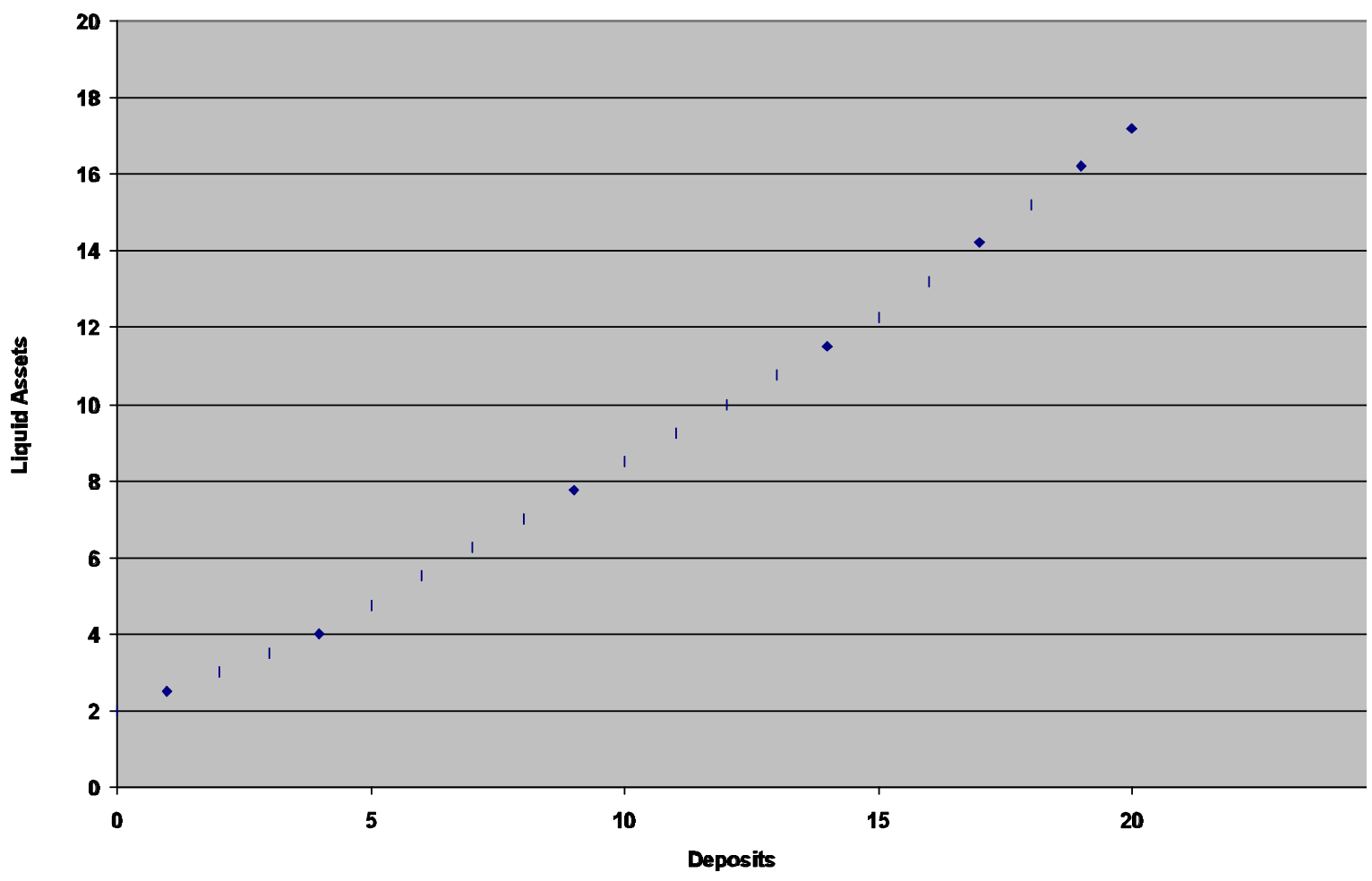

Figure 1B. Relationship between Commitments and Deposits

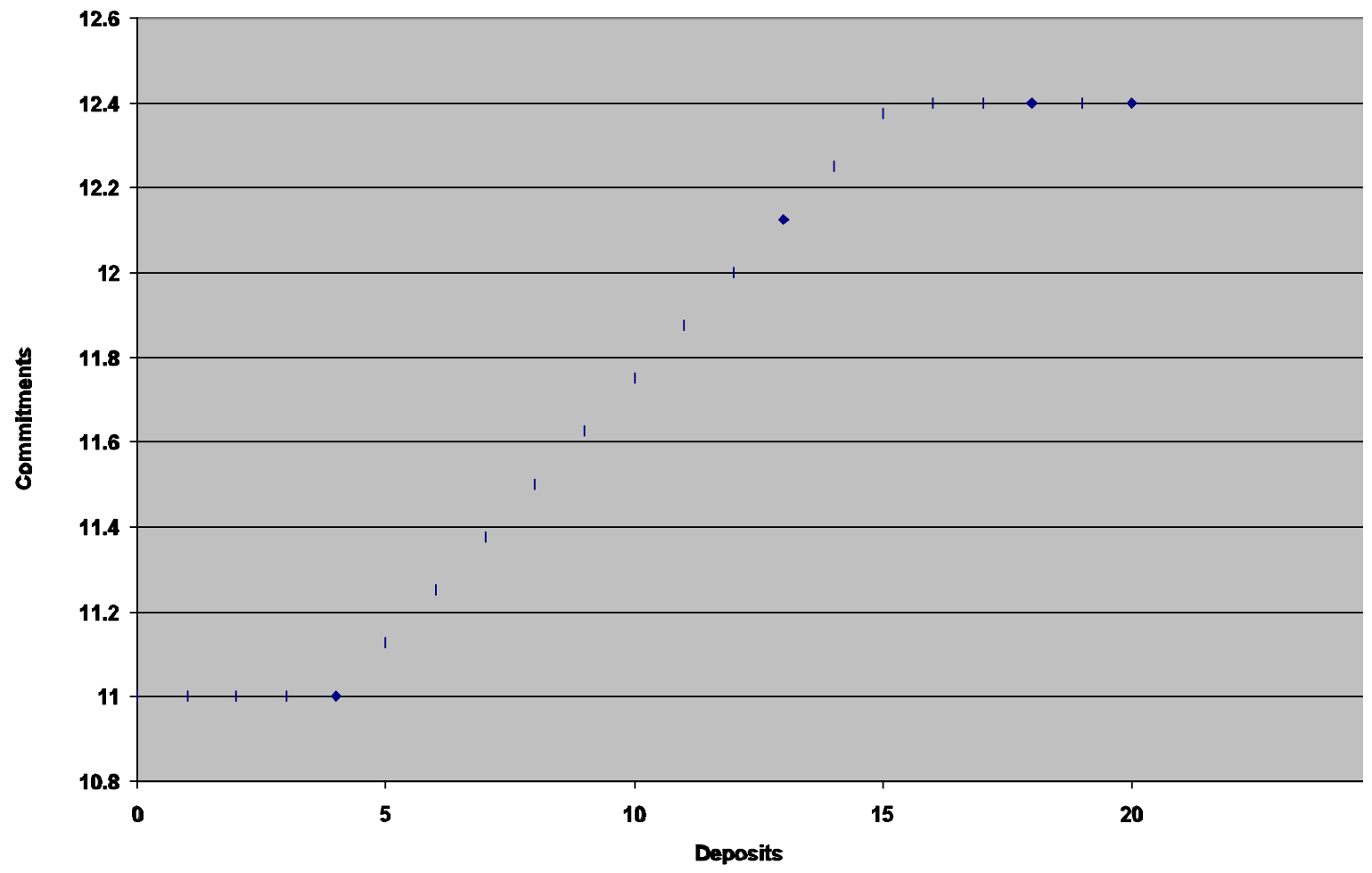


